\title{
The Determinant of Hypertension on Pre-Elderly and Elderly Prolanis in Sukowono Primary Health Center Jember Regency in 2019
}

\author{
${ }^{1}$ Ardhi Nur Rahmad, ${ }^{2}$ Farida Wahyu Ningtyias, ${ }^{3}$ Ninna Rohmawati \\ ${ }^{123}$ Faculty of Public Health, Jember University, Indonesia \\ Coresponding author: Ardhi Nur Rahmad, e-mail: radenardhi96@gmail.com \\ Co-author: FWN: farida.fkm@unej.ac.id, NR: ninna.rohmawati@gmail.com \\ Submitted: $01 / 03 / 2020$ \\ Revised: $19 / 04 / 2020$ \\ Accepted: $19 / 04 / 2020$ \\ Published online: $21 / 04 / 2020$ \\ doi: https://doi.org/10.35308/j-kesmas.v7i1.1865 How to cite this article: Rahmad, A.N., Ningtyias, F.W., \& Rohmawati, N. \\ (2020). The determinant of hypertension on pre-elderly and elderly prolanis in Sukowono Primary Health Center Jember \\ Regency in 2019. J-Kesmas: Jurnal Fakultas Kesehatan Masyarakat (The Indonesian Journal of Public Health), 7(1): 6-12.
}

\begin{abstract}
Hypertension is a main health problem throughout the world, in addition to its high prevalence, hypertension is also associated with an increased risk of cardiovascular disease. The reasearch was to analyze the relation between levels of sosialeconomic, levels of sodium and saturated fat consumption, the levels of physical activity, nutritional status, coffee, smoking, and the levels of stress with hypertension of Prolanis pre-elderly and elderly in Sukowono Primary Health Center, Jember Regency. The research was observational analytic study with cross sectional design. The population of this research were 48 respondents. The sampling technique was total sampling. The data analyzed by using bivariate analysis with Chi-Square test. The result of analysis in this research showed that there was a correlation between the level of sodium consumption with the incidence of hypertension. There was no correlation between socioeconomic (employment and the minimum earning) (p-value $=0.282$ and $p$-value $=0.770>0.05)$, the levels of saturated fat $(p$-value $=1.000>0.05)$, the levels of physical activity ( $p$-value $=0.074>0.05)$, nutritional status ( $\mathrm{p}$-value $=0.799>0.05)$, consumption coffee ( $\mathrm{p}$-value $=1.000>0.05)$, smoking $(\mathrm{p}$-value $=$ $1.000>0.05)$, and the levels of stress ( $\mathrm{p}$-value $=0.126>0.05)$ with hypertension. There was correlation between the levels of sodium consumption with hypertension $(\mathrm{p}$-value $=0.000<0.05)$.
\end{abstract}

Keywords: hypertension, pre-elderly, elderly, prolanis

\section{Introduction}

The World Health Organization (WHO) defines the hypertension or high blood pressure as a condition that is a continual increase in blood pressure. Others researchers said that the suffer of hypertension who has the systolic pressure $>140$ $\mathrm{mmHg}$ and the diastolic pressure $>90 \mathrm{mmHg}$.

Based on data was obtained from WHO and The International Society of Hypertension (ISH) there were 600 million people with hypertension worldwide, and 3 million of them die every year, where 7 out of 10 of these patients did not get adequate treatment (Rahajeng, 2009).

Based on data on 10 pre-elderly and elderly health's problems in Indonesia, hypertension is on first rank with prevalence that continued to increase at the age of the age group that is 55-64 years old (45.9\%), 65-74 years old (57.6\%) and age 75 years and over $(63.9 \%)$ (Ministry of Health, 2016). In Indonesia, Hypertension was on third rank cause of death after stroke and tuberculosis which is $6.7 \%$ of the population of death at all ages. In Sukowono Sub-
District, there were 1,425 suffer of hypertension (Jember Health Office).

In Indonesia, East Java Province was at rank 6th after South Kalimantan, West Java, East Kalimantan, Central Java, West Kalimantan. In Jember Regency in 2018, the prevalence of preelderly and elderly hypertension was 58,494 people suffering from hypertension. In 2017, the prevalence of hypertension in Sukowono Sub-District was at first rank with a total of 3,922 suffers. Bustami (2018) described that hypertension patient prevalence in $\mathrm{Cut}$ Nyak Dhien Hospital, Meulaboh. Hence, The reasearch was to analyze the relation between levels of sosialeconomic, levels of sodium and saturated fat consumption, the levels of physical activity, nutritional status, coffee, smoking, and the levels of stress with hypertension of Prolanis pre-elderly and elderly in Sukowono Primary Health Center, Jember Regency.

\section{Materials and Method}

This study used a quantitative research design with a cross sectional approach which was conducted 
on Prolanis in Puskesmas Sukowono Jember Regency on March-April 2019. The population in this study were all pre-elderly and elderly who followed in Prolanis. The sample were 48 respondents. The data analysis used was bivariate (chi-square).

\section{Results}

Table 1. The analysis of the correlation between social economy with hypertension on pre-elderly and elderly in Puskesmas Sukowono of Jember Regency

\begin{tabular}{cc}
\hline Variable & $\mathrm{p}$-value \\
\hline Occupational Status & \\
\hline Work & $\mathrm{p}=0,282(\mathrm{p}>0,282)$ \\
Didn't Work/Retired & \\
\hline Earnings & \\
\hline $1.916 .983,99$ & $\mathrm{p}=0,770(\mathrm{p}>0,770)$ \\
$<1.916 .983,99$ & \\
\hline
\end{tabular}

Table 2. The analysis of the correlation between the levels of sodium consumption with hypertension on pre-elderly and elderly in Puskesmas Sukowono of Jember Regency

\begin{tabular}{cc}
\hline Variable & $\mathrm{p}$-value \\
\hline $\begin{array}{c}\text { The Levels of Sodium } \\
\text { Consumption }\end{array}$ & \\
\hline$>2400 \mathrm{mg}$ & $\mathrm{p}=0,000(\mathrm{p}<0,05)$ \\
$\leq 2400 \mathrm{mg}$ & \\
\hline
\end{tabular}

Table 3. The analysis of the correlation between the levels of saturated fat consumption with hypertension on pre-elderly and elderly in Puskesmas Sukowono of Jember Regency

\begin{tabular}{cc}
\hline Variable & $\mathrm{p}$-value \\
\hline $\begin{array}{c}\text { The Levels of Saturated Fat } \\
\text { Consumption }\end{array}$ & \\
\hline Defisit & $\mathrm{p}=1,000(\mathrm{p}>0,05)$ \\
Normal & \\
Over & \\
\hline
\end{tabular}

Table 4. The analysis of the correlation between the levels of physical activities with hypertension on preelderly and elderly in Puskesmas Sukowono of Jember Regency

\begin{tabular}{cc}
\hline Variable & $\mathrm{p}$-value \\
\hline $\begin{array}{c}\text { The Levels of Physical } \\
\text { Activities }\end{array}$ & \\
\hline $\begin{array}{c}\text { Good Physical Activities } \\
\text { Less Physical Activities }\end{array}$ & $\mathrm{p}=0,074(\mathrm{p}>0,05)$ \\
\hline
\end{tabular}


Table 5. The analysis of the correlation between nutritional status with hypertension on pre-elderly and elderly in Puskesmas Sukowono of Jember Regency

\begin{tabular}{cc}
\hline Variable & $\mathrm{p}$-value \\
\hline Nutritional Status & \\
\hline Normal & $\mathrm{p}=0,799(\mathrm{p}>0,05)$ \\
Obesity & \\
\hline
\end{tabular}

Table 6. The analysis of the correlation between coffee consumption with hypertension on pre-elderly and elderly in Puskesmas Sukowono of Jember Regency

\begin{tabular}{cc}
\hline Variable & p-value \\
\hline Coffee Consumption & \\
\hline Yes & $\mathrm{p}=1,000(\mathrm{p}>0,05)$ \\
No & \\
\hline
\end{tabular}

Table 7. The analysis of the correlation between smoking with hypertension on pre-elderly and elderly in Puskesmas Sukowono of Jember Regency

\begin{tabular}{cc}
\hline Variable & p-value \\
\hline Smoking & \\
\hline Yes & $\mathrm{p}=1,000(\mathrm{p}>0,05)$ \\
No & \\
\hline
\end{tabular}

Table 8. The analysis of the correlation between the levels of stress with hypertension on pre-elderly and elderly in Puskesmas Sukowono of Jember Regency

\begin{tabular}{cc}
\hline Variable & $\mathrm{p}$-value \\
\hline The Levels of Stress & $\mathrm{p}=1,000(\mathrm{p}>0,05)$ \\
Normal & \\
Mild & \\
Average & \\
\hline
\end{tabular}

\section{Discussion}

\section{Social economic}

As shown in Table 1, analysis test result has an expected count value $<5$ of $25 \%$ ( $>20 \%$ ). It showed that the result of the analysis did not meet the requirements of the chi-square test, so the analysis used the Fisher's Exact Test. The result of the analysis showed that $\mathrm{p}$ value $>\alpha(0.05)$ was 0.282 , so it could be concluded that the employment status was not correlated to the incidence of hypertension.
The result of the analysis on the correlation between earnings level with the incidence of hypertension showed that the highest income levels in the elderly and Prolanis were each of 24 respondents $(50 \%)$ whose the level of income was more than UMR and less than UMR. The analysis test result has an expected count value $<5$ of $0 \%$. It showed that the result of the analysis met the requirements of the chi-square test, so the analysis used Continuity Correction. The result of the analysis showed that $p$ value $>\alpha(0.05)$ was 0.770 , so it could be concluded that the level of income was not correlated to the incidence of hypertension.

Elderly when entering retirement tend to experience a sharp decline in income and increasingly inadequate. Frequent emergence of major functional problems (Maryam et al., 2008). The result of this study was in line with research conducted by Fitriana (2015) which states that there was no correlation between socioeconomics and the incidence of hypertension.

\section{The levels of sodium consumption}

The result of the analysis on the correlation between the level of sodium consumption with the incidence of hypertension as shown in Table 2, the most is the level of sodium consumption $>2400 \mathrm{mg}$. Prolanis classified consumed sodium $>2400 \mathrm{mg}$ were 32 respondents $(66.7 \%)$. The analysis test result has an expected count value $<5$ of $0 \%(<20 \%)$. It showed that the result of the analysis met the requirements of the chi-square test, so the analysis used Continuity Correction. The result of the analysis showed that the $p$ value $<\alpha(0.05)$ was 0.000 , so it could be concluded that the level of sodium consumption was correlated to the incidence of hypertension.

The result of this study was in line with the research of Darmawan et al. (2018) and Wahyuni et al. (2014). Sodium is associated with the occurrence of high blood pressure because high salt consumption can narrow the diameter of the arteries, so the heart must pump harder to push the volume of blood that gets narrower and will cause blood pressure to increase. The opposite will also happen when sodium intake reduces so does the blood volume and blood pressure in some individuals.

The effect of sodium intake on the level of hypertension occurs through an increase in plasma volume and blood pressure. People who consume small amounts of salt have a lower history of hypertension. Excessive sodium consumption makes the composition of sodium in the liquid in the extracellular fluid to increase. To normalize again, intracellular fluid must be pulled out so that the 
volume of extracellular fluid increases. Increased extracellular fluid causes an increase in blood volume rises, resulting in hypertension (Atun, 2014).

\section{The levels of saturated fat consumption}

The result of the analysis on the correlation between the level of saturated fat consumption with the incidence of hypertension showed that the most is the level of saturated fat consumption in the elderly and the elderly classified as deficit. Pre elderly and elderly classified as a deficit of 40 respondents $(83.3 \%)$. The analysis test result has an expected count value of $>5$ of $50 \%(>20 \%)$. It showed that the result of the analysis did not meet the requirements of the chi-square test, so the analysis used Fisher Exact. The result of the analysis showed that $\mathrm{p}$ value $>\alpha(0.05)$ is 1.000 , so it could be concluded that the level of saturated fat consumption was not correlated to the incidence of hypertension (Tabel 3).

This was in line with research conducted by Ismuningsih (2016) and Rawasiah et al. (2012) which states that there was no correlation between saturated fat consumption and the incidence of hypertension with $p$-values of 0.150 and $0.303(p>0.05)$.

There was no correlation between the level of consumption due to the $2 \times 24$ hour Food Recall conducted, the level of consumption of saturated fat consumed including a mild deficit of 39 respondents. The pattern of saturated fat consumption is done using the Food Frequency Questionnaire (FFQ) questionnaire, respondents only consume coconut oil as much as 48 respondents and coconut milk as much as 2 respondents. Excessive fat consumption can pose a risk of hypertension because it will increase cholesterol levels in the blood. Cholesterol will be attached to the walls of blood vessels which over time the blood vessels will become blocked due to the presence of plaque in the blood called atherosclerosis. Plaque that is formed will result in narrowed blood flow so that blood volume and blood pressure will increase. Therefore, consumption of fat that is not excessive or good can reduce the risk of hypertension (Morrell, 2005).

\section{The levels of physical activities}

The result of the analysis on the correlation between the level of physical activity and the incidence of hypertension showed that the highest level of physical activity in the elderly and the elderly was classified as good as many as 31 respondents (64.6\%). Analysis test result have an expected count value $<5$ of $25 \%(>20 \%)$ as shown in Table 4 . It shows that the result of the analysis did not meet the requirements of the chi-square test, so the analysis used the Fisher's Exact Test. The result of the analysis showed that $p$ value $>\alpha(0.05)$ was 0.074 , so it could be concluded that the level of physical activity is not correlated to the incidence of hypertension.

The result of this study was in line with Novitaningtyas (2013) and Julianti et al. (2015) which states that there was no correlation between physical activity and the incidence of hypertension with $\mathrm{p}$-values of 0.538 and $0.651(\mathrm{p}>0.05)$ However, the result of this study was not in line with the research of Iswahyuni (2017) states that there was a correlation between physical activity and hypertension with each p-value of 0.000 .

There was no correlation between the level of physical activity with the incidence of hypertension due to the level of physical activity of respondents which is included in the good category of 34 respondents. Regular physical activity helps improve overall heart efficiency. A person who is physically active generally has lower blood pressure and is less likely to get high blood pressure. Those who is physically active tend to have better muscle and joint function, because such organs are stronger and more flexible. Activities in the form of movements or aerobic exercise are useful to improve and maintain fitness, cardio-respiratory endurance. Examples of aerobic exercises are like walking, jogging, swimming, and cycling. Aerobic exercise makes the muscles of the body work. Various studies have shown that people who have low fitness levels do not move very much. If each day rise an average of 25 to 30 steps, 5 times a week within 12 to 30 weeks can significantly improve cardio-respiratory fitness. Regular and measured exercise can absorb or eliminate cholesterol deposits in the arteries. Physical activity that is carried out regularly causes changes such as the heart will get stronger in the smooth muscle so that the capacity is large and the construction or pulse is strong and regular, besides that the elasticity of blood vessels will increase due to relaxation and vasodilation so that saturated fat deposits will decrease and increase muscle contraction of blood vessel walls.

\section{Nutritional status}

The result of the analysis on the correlation between nutritional status and the incidence of hypertension as shown in Table 5, the most nutritional status in the elderly and Prolanis was classified as normal nutritional status by 31 respondents $(64.6 \%)$. The analysis test result has an expected count value $<5$ of $50 \%(>20 \%)$. It showed that the result of the analysis did not meet the 
requirements of the chi-square test, so the analysis used merging cells into $2 \times 2$ tables and met the requirements of the chi-square test so that it used the Continuity Correction test. The result of the analysis showed that $p$ value $>\alpha(0.05)$ was 0.799 , so it could be concluded that nutritional status is not correlated to hypertension.

The result of this study was in line with Ratnaningrum (2014) which states that there was no correlation between nutritional status and the incidence of hypertension with p-value of 0.412 ( $p>$ 0.05 ). But the result of this study was not in line with research by Asrinawaty (2014) and Darmawan et al. (2018) stating that there was a correlation between nutritional status and the incidence of hypertension with each p-value of 0.031 and $0.001(\mathrm{p}<0.05)$.

There was no correlation between nutritional status with the incidence of hypertension due to the nutritional status of the elderly and the elderly prolanis classified as normal. Normal nutritional status can decrease the risk of hypertension. According to the Ministry of Health (2006), the relative risk for suffering from hypertension in obese people is 5 times higher compared to normal weight people, besides that the Body Mass Index (BMI) is directly correlated with blood pressure especially systolic blood pressure. Nutrition further increases the risk of hypertension due to several reasons. The greater the body's mass, the more blood is needed to supply oxygen and food to body tissues. This means that the volume of blood circulating through the blood vessels increases so that it gives greater pressure to the arterial wall which will cause an increase in blood pressure. In addition, being overweight also increases the frequency of heart rates (Sheps, 2005).

\section{Coffee consumption}

The result of the analysis on the correlation between coffee consumption and the incidence of hypertension showed that the most in the elderly and Prolanis elderly not consuming coffee were 30 respondents $(62.5 \%)$. The analysis test result has an expected count value $<5$ of $0 \%$. It showed that the result of the analysis met the requirements of the chisquare test, so the analysis used Continuity Correction. The result of the analysis showed that $p$ value $>\alpha(0.05)$ was 1.000 , so it could be concluded that coffee consumption was not correlated to the incidence of hypertension as shown in Table 6 .

The result of this study was in line with the research of Ruus et al. (2015) and Mullo et al. (2018) which states that there was no correlation between coffee consumption with the incidence of hypertension with $p$-values of 0.942 and 0.335 respectively $(\mathrm{p}>0.05)$ But the result of this study was not in line with Wahyuni's (2013) which states that there was a correlation between coffee consumption and the incidence of hypertension with $\mathrm{p}$-value of 0.000 each $(\mathrm{p}<0.05)$.

There was no correlation between coffee consumption with the incidence of hypertension because most respondents do not consume coffee. Do not consume coffee and only consume no more than 2 cups of coffee can reduce the risk of hypertension. Syafiq (2017) explained that the average increase in systolic blood pressure was $2 \mathrm{mmHg}$ and diastolic blood pressure as much as $3 \mathrm{mmHg}$ in six respondents who were given coffee with a coffee content of $100 \mathrm{mg}$. This is caused by the coffee in coffee inhibits adenosine receptors in the central nervous system which will stimulate the production of the hormone adrenaline and cause increased blood pressure and muscle activity and the stimulation of the liver to release sugar compounds in the bloodstream to produce extra. Coffee has endogenous antagonistic properties of adenosine so it can cause vascular construction and increased peripheral vascular resistance (Hasri et al., 2012). This mechanism becomes fully active in 30 minutes to two hours (Guyton, 2007).

\section{Smoking}

The result of the analysis on the correlation between smoking and the incidence of hypertension as shown in Table 7, the most in the elderly and elderly Prolanis that is not smoking as many as 40 respondents $(85 \%)$. The analysis test result has an expected count value $<5$ of $50 \%$ ( $>20 \%$ ). It showed that the result of the analysis did not meet the requirements of the chi-square test, so the analysis uses the Fisher's Exact Test. The result of the analysis showed that $p$ value $>\alpha(0.05)$ is 1.000 , so it could be concluded that smoking is not correlated to the incidence of hypertension.

The result of this study was in line with the research of Uguy et al. (2019) which states that there was no correlation between smoking and the incidence of hypertension with a p-value of 0.795 (p> $0.05)$, but the result of this study was not in line with the research Setyanda et al (2015) and Retnaningsih et al (2016) which states that there was a correlation between smoking and the incidence of hypertension with p-values of 0.003 and $0.000 \quad(p<0.05)$, respectively.

There was no correlation between smoking and the incidence of hypertension because most respondents do not smoke but have hypertension. Hypertension has several factors, not just smoking (multicausal). Several studies have shown that the 
most influential factor is age. Increasing age vulnerable to increased blood pressure, arterial walls thickening due to the accumulation of collagen substances, so that blood vessels narrow and become stiff. In this study, most respondents aged 45 years and over. This is what causes the effect of smoking not found in this study.

\section{The levels of stress}

The result of the analysis on the correlation between stress and the incidence of hypertension showed that stress in the elderly and the most elderly was classified as normal. The analysis test result has an expected count value $<5$ of $0 \%$. It showed that the analysis result in the $2 \times 2$ table meet the chi-square test requirements, so the analysis used Continuity Correction. The result of the analysis showed that $p$ value $>\alpha(0.05)$ was 0.126 , so it could be concluded that stress was not correlated to the incidence of hypertension as shown in Table 8 .

The result of this study is in line with research by Bahri (2014) and Lidia et al. (2018) which states that there was no correlation between stress and the incidence of hypertension with p-values of 0.265 and 0.071 ( $p>0.05$, respectively) ) However, the result of this study was not in line with the research of Hermawan (2014) and Susanto (2011) which states that there was a correlation between stress and the incidence of hypertension with p-values of 0.013 and $0.002(\mathrm{p}<0.05))$.

There was no correlation between stress with the incidence of hypertension due to pre-elderly stress and elderly prolanis classified as normal. Someone who has normal and mild stress levels tends to have a lower risk than someone who has moderate or severe stress levels. According to Novian (2013), stress is believed to be correlated to hypertension suspected through sympathetic nerve activity. Increased sympathetic nerve activity can increase blood pressure erratically. Stress can cause blood pressure to rise for a while, and if the stress has

\section{References}

Asrinawaty \& Norfai (2014) Hubungan status gizi dengan kejadian hipertensi pra lansia dan lansia di posyandu pra lansia dan lansia kakaktua wilayah kerja puskesmas pelambuan. Artikel Ilmiah VII. Banjarmasin: Fakultas Kesehatan Masyarakat Uniska.

Atun, L. (2014) Asupan sumber natrium, rasio kalium natrium, aktivitas fisik, dan tekanan darah pada pasien. MGML. 6(1): 63-71.

Bahri, S. (2014) Hubungan antara tingkat stres dengan kejadian hipertensi pada lansia di Panti Wredha disappeared or passed, blood pressure will return to normal.

\section{Conclusion}

There was a correlation between the level of sodium consumption with the incidence of hypertension. There was no correlation between: (1) the level of saturated fat consumption with the incidence of hypertension, (2) between work status and the incidence of hypertension, and between income and the incidence of hypertension, (3) between the level of physical activity and the incidence of hypertension, (4) between nutritional status and the incidence of hypertension, (5) between coffee consumption and the incidence of hypertension, (6) between smoking and the incidence of hypertension, (7) between stress and the incidence of hypertension.

\section{Acknowledgement}

Thanks to all who have helped to finish this research, especially to the health department and all my research respondents who were willing to be interviewed.

\section{Author Contribution and Competing Interest}

All of the authors contributed in collecting and analyzing the data, including preparing the manuscript. The was no competing interest related to the conduct of this study.

\section{Publisher's Note}

J-Kesmas: Jurnal Fakultas Kesehatan Masyarakat (Indonesia Journal of Public Health) remains neutral with regard to jurisdictional claims in published institutional affiliation.

Budi Dharma Yogyakarta. Skripsi. Yogyakarta: STIKES Aisyiyah Yogyakarta.

Bustami (2018) Perbedaan tekanan darah pada pasien hipertensi antara pasien dengan indeks massa tubuh normal dengan overweigh dan obesitas di Poli Klinik Penyakit Dalam Blud Rumah Sakit Umum Cut Nyak Dhien Meulaboh. J-Kesmas: Jurnal Fakultas Kesehatan Masyarakat (Indones. J. Pub. Health), 5(1): 33-39.

Darmawan, H., Tamrin, A., \& Nadimin (2018) Asupan natrium dan status gizi terhadap tingkat hipertensi 
pada pasien rawat jalan di RSUD Kota Makassar. Jurnal Media Gizi Pangan, 25(1): 11-17.

Fitriana, R. (2015) Hubungan antara konsumsi makanan dan status gizi dengan kejadian hipertensi pada lansia (Studi di Posyandu Lansia Wilayah Kerja Puskesmas Wuluhan Kabupaten Jember). Skripsi. Jember: Fakultas Kesehatan Masyarakat Universitas Jember.

Guyton (2007) Buku ajar fisiologi kedokteran Edisi 11. Jakarta: Penerbit Buku Kedokteran EGC.

Hasri, M., Wahiduddin. \& Rismayanti (2012) Faktor risiko kejadian hipertensi di Wilayah Kerja Puskesmas Bangkala Kabupaten Jeneponto Tahun 2012. Jurnal Ilmu Kesehatan Masyarakat, 5(5): 10-12.

Ismuningsih, R. (2013) Pengaruh konsumsi lemak terhadap tekanan darah penderita hipertensi rawat jalan di Rumah Sakit PKU Muhammdiyah Surakarta. Skripsi. Surakarta: Universitas Muhammadiyah Surakarta.

JNC VII (2013) The Seventh Report of the Joint National Committee on Detection, Evaluation, and Treatment of High Blood Pressure. Boston: National Heart, Lung, and Blood Institute.

Julianti, A., Pangasuti, R., \& Ulvie, Y.N.S. (2015) Hubungan antara obesitas dan aktivitas fisik dengan tekanan darah pasien hipertensi. Jurnal Media Ilmu Keolahragaan Indonesia. 5(1): 9-12.

Lidia, R., Musafaah \& Hafifah, I. (2018) Hubungan tingkat stres dengan kejadian hipertensi pada lansia di Puskesmas Rawat Inap Cempaka. Jurnal Keperawatan STIKES Suaka Insan, 3(1): 1-7.

Mannan (2012) Faktor risiko kejadian hipertensi di wilayah kerja puskesmas bangkala kabupaten Jeneponto Tahun 2012. Jurnal MKMI 16(1): 1-12.

Maryam., Ekasari., Rosidawati., \& Junaedi (2008) Mengenal usia lanjut dan perawatannya. Jakarta: Salemba Medika.

Morrell (2005) Kolesterol. Jakarta: Erlangga.

Mullo, O.E., Langi, F.L.F.G., \& Asrifuddin, A. (2018) Hubungan antara kebiasaan minum kopi dengan kejadian hipertensi di wilayah kerja Puskesmas Paniki Bawah Kota Manado. Jurnal Kesmas, 7(5): 6-7.

Novian, A (2013) Faktor yang berhubungan dengan kepatuhan diit pasien hipertensi (Studi pada pasien rawat jalan di Rumah Sakit Islam Sultan Agung Semarang Tahun 2013). Skripsi. Semarang: Universitas Negeri Semarang.

Novitaningtyas, T. (2013) Hubungan karakteristik (umur, jenis kelamin, tingkat pendidikan) dan aktivitas fisik dengan tekanan darah pada lansia di Kelurahan Makam Haji Kecamatan Kartasura Kabupaten Sukoharjo. Skripsi. Surakarta: Universitas Muhammadiyah Surakarta

Pusat Data dan Informasi Kemenkes RI. (2013) Gambaran kesehatan pra lansia dan lansia di Indonesia. Jakarta: Buletin Jendela Data dan Informasi Kesehatan.

Rahajeng, E., \& Tuminah, S. (2009) Prevalensi hipertensi dan determinannya di Indonesia. Jakarta: Pusat Penelitian Biomedis dan Farmasi Badan Penelitian Kesehatan Departemen Kesehatan RI.
Ratnaningrum, D.P.S.Y. (2015) Hubungan asupan serat dan status gizi dengan tekanan darah pada wanita menopause di Desa Kuwiran Kecamatan Banyudono Kabupaten Boyolali. Skripsi. Surakarta: Fakultas Ilmu Kesehatan Universitas Muhammadiyah Surakarta.

Retnaningsih, D., Kustriyani, M., \& Sanjaya, B.T. (2017) Perilaku merokok dengan kejadian hipertensi pada lansia. Jurnal Universitas Muhammadiyah Semarang, 8(2): 1-9.

Rawasiah, A.R., Wahiduddin, \& Rismayanti. (2012). Hubungan faktor konsumsi makanan dengan kejadian hipertensi pada lansia di puskesmas pattingalloang. Jurnal MKMI, 16(1): 1-9.

Riset Kesehatan Dasar (2013) Badan Penelitian dan Pengembangan Kesehatan Kementrian RI Tahun 2013. Diakses online: www.litbang.depkes.go.id

Ruus, M., Kepel, B.J., \& Umboh, J.M.L. (2015) Hubungan antara konsumsi alkohol dan kopi dengan kejadian hipertensi pada laki-laki di Desa Ongkaw Dua Kecamatan Sinonsayang Kabupaten Minahasa Selatan. E-Jurnal Unsrat, 5(1): 65-72.

Setyanda, Y.O.G., Sulastri, D., \& Lestari, Y. (2015) Hubungan merokok dengan kejadian hipertensi pada laki-laki usia 35-65 tahun di Kota Padang. Jurnal Kesehatan Andalas, 4(2): 434-440.

Sheps, Sheldon G, (2005). Mayo clinic hipertensi, mengatasi tekanan darah tinggi. Jakarta: PT Intisari Mediatama.

Susanto, A. (2011) Hubungan antara stres dengan kejadian hipertensi pada lansia di Dusun 14 Sungapan, Galur Kulon Progo Tahun 2011. Skripsi. Yogyakarta: STIKES Aisyiyah Yogyakarta.

Syafiq, \& Fikawati (2007) Gizi dan kesehatan masyarakat. Jakarta: Raja Grafindo Persada.

Uguy, J.M., Nelwan, J.E., \& Sekeon, S.A.S. (2019) Kebiasaan merokok dan kejadian hipertensi di Wilayah Kerja Puskesmas Melompar Belang Kecamatan Belang Kabupaten Minahasa Tenggara Tahun 2018. Jurnal KESMAS, 8(1): 4448.

Wahyuni, E.R., Siregar, A. \& Lubis, Z. (2014) Hubungan asupan natrium dengan kejadian hipertensi di UPT Pelayanan Sosial Lanjuut Usia Binjai Tahun 2015. Jurnal Universitas Sumatera Utara, 1(1): $1-7$. 